\title{
EVALUASI BAHAN BAKU PAKAN DAN PENGEMBANGAN PAKAN BUATAN UNTUK BUDIDAYA PEMBESARAN ABALON (Haliotis squamata)
}

\author{
Nyoman Adiasmara Giri\#, Muhammad Marzuqi, Ni Wayan Widya Astuti, \\ Wawan Andriyanto, Ibnu Rusdi, dan Retno Andamari
}

Balai Besar Penelitian dan Pengembangan Budidaya Laut

(Naskah diterima: 30 Juli 2015; Revisi final: 31 Agustus 2015; Disetujui publikasi: 2 September 2015)

\begin{abstract}
ABSTRAK
Abalon merupakan salah satu jenis moluska laut yang memiliki nilai ekonomis penting dan spesies unggulan untuk budidaya di Indonesia. Keberhasilan budidaya abalon ditentukan oleh ketersediaan benih yang memadai. Selain itu, ketersediaan pakan yang baik juga berpengaruh nyata terhadap pertumbuhan abalon. Efektivitas pakan buatan untuk pembesaran abalon dipengaruhi oleh bahan baku yang digunakan. Untuk itu, penelitian ini bertujuan mendapatkan informasi dasar tentang bahan baku untuk pengembangan pakan buatan dan respons pertumbuhan abalon $H$. squamata terhadap pakan buatan. Bahan baku pakan dikoleksi, dianalisis komposisi nutriennya yang meliputi komposisi proksimat, asam amino, dan asam lemaknya. Percobaan aplikasi pakan buatan berbahan baku rumput laut dilakukan di Laboratorium Pakan, Balai Besar Penelitian dan Pengembangan Budidaya Laut, Gondol. Empat pakan percobaan dengan kombinasi tepung rumput laut berbeda dibuat dalam bentuk pelet kering. Sebagai pakan kontrol digunakan Gracilaria

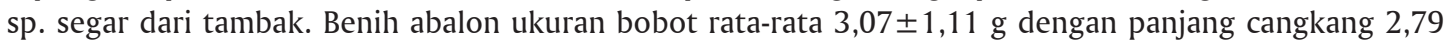
$\pm 0,27 \mathrm{~cm}$ dipelihara dalam bak beton ukuran $2 \mathrm{~m}$ x 0,5 m x 0,5 m dengan kepadatan 400 ekor/bak. Bak dilengkapi dengan sistem air mengalir dan aerasi. Abalon diberi pakan percobaan dua kali sehari, pagi, dan sore hari. Percobaan dirancang dengan rancangan acak lengkap dengan lima perlakuan dan tiga ulangan untuk setiap perlakuan. Pada penelitian ini diperoleh empat jenis rumput laut yang potensial dapat dimanfaatkan sebagai bahan baku pakan abalon $H$. squamata. Hasil uji pakan menunjukkan bahwa pakan dari campuran tepung rumput laut Gracilaria sp. tambak dengan Ulva sp. (2:1) atau campuran Gracilaria sp. tambak dengan Sargassum sp. (2,3:1) memberikan respons pertumbuhan abalon $H$. squamata yang baik.
\end{abstract}

KATA KUNCI: abalon, pembesaran, bahan baku, pengembangan pakan

ABSTRACT: Evaluation of potential feedstuffs and development of compound feed for grow-out of abalone (Haliotis squamata). By: Nyoman Adiasmara Giri, Muhammad Marzuqi, Ni Wayan Widya Astuti, Wawan Andriyanto, Ibnu Rusdi, and Retno Andamari

\begin{abstract}
Abalone is one type of marine mollusks that has a good prospect in terms of price, market share and simple culture technique. Success of abalone farming depended on the availability of adequate seed. In addition, the availability of good food also significantly affect the growth of abalone. Effectiveness of artificial diets for abalone is influenced by the feedstuffs used for diet. Therefore, this research aims to obtain basic information on the feedstuffs for the development of artificial diet and to know growth response of abalone H. squamata fed that artificial diet. Collected feedstuffs were analyzed for proximate, amino acids, and fatty acids composition. Feeding trial on applications of artificial diet prepared from seaweed has been conducted at the Nutrition Laboratory of Institute for Mariculture Research and Development, Gondol. Four experimental diets with different combinations of seaweed meal were prepared as dry pellet. Fresh Gracilaria sp. from pound culture was used as control diet. Juvenile abalone with average weight of $3.07 \pm 1.11 \mathrm{~g}$ with $2.79 \pm 0.27 \mathrm{~cm}$ shell length were reared in the concrete tank of $2 \mathrm{~m} \times 0.5 \mathrm{~m} \times 0.5 \mathrm{~m}$ with a density of 400 pcs/tank. Tanks were equipped with flow-through sea water and aeration systems. Abalone fed experimental diet two times a day, at the morning, and afternoon. The experiment was designed with a completely randomized design, with five treatments and three replications for each treatment. Present study have shown that four
\end{abstract}

\# Korespondensi: Balai Besar Penelitian dan Pengembangan Budidaya Laut. Jl. Br. Gondol Kec. Gerokgak Kab. Buleleng, Kotak Pos 140, Singaraja, Bali 81101, Indonesia. Tel.: + (0362) 92278

E-mail: adiasmaranyoman@yahoo.com 
kinds of seaweed that can potentially be used as a feedstuff for abalone feed. Result of feeding trial showed that the diet prepared from mixture of Gracilaria sp. with Ulva sp. meal or a mixture of Gracilaria sp. from pond culture with Sargassum sp. meal provide a good growth response of abalone $H$. squamata.

KEYWORDS: $\quad$ abalones, grow-out, feedstuff, feed development

\section{PENDAHULUAN}

Abalon merupakan salah satu jenis moluska laut yang memiliki potensi untuk dikembangkan usaha budidayanya. Negara penghasil abalon budidaya di antaranya: Cina, Jepang, Taiwan, Afrika Selatan, Australia, Amerika Serikat, Meksiko, Irlandia, Islandia, dan Selandia Baru (Hahn, 1989; Gordon \& Cook, 2001). Di alam dilaporkan terdapat sekitar 100 spesies abalon yang berasal dari genus Haliotis, namun hanya sekitar sepuluh spesies yang memiliki nilai komersil (Takashi, 1980). Sedangkan di Jepang dilaporkan terdapat tujuh spesies, yaitu Haliotis asinina, H. gigantea, $H$. sieboldii, $H$. discus, $H$. discus hannai, $H$. diversicolor, dan H. supertexta (Ikenoue \& Kafuku, 1992).

Di Indonesia telah berhasil dikembangkan teknologi pembenihan untuk dua spesies abalon, yaitu $H$. asinina dan $H$. squamata. Pengembangan teknik pembenihan abalon $H$. squamata dimulai dengan domestikasi, pematangan gonad, pemijahan induk secara alami maupun rangsangan, serta teknik pemeliharaan larva sampai mencapai ukuran benih telah dikuasai (Susanto et al., 2008; Rusdi et al., 2010; Susanto et al., 2010). Aplikasi teknologi pembenihan abalon $H$. squamata telah berhasil memproduksi benih secara massal di hatcheri dengan sintasan berkisar 3,3\%-18,4\% sampai benih umur dua bulan (Susanto et al., 2009; Rusdi et al., 2012). Dengan tersedianya benih ini mendorong dikembangkannya usaha budidaya pembesaran abalon, baik di laut maupun dengan menggunakan bak di darat. Uji coba pembesaran abalon di laut dengan beberapa metode dan menggunakan pakan makro alga segar menunjukkan hasil yang baik (Sutarmat et al., 2009).

Abalon (Haliotis sp.) merupakan hewan laut yang bersifat herbivora dan banyak memanfaatkan rumput laut dari golongan alga merah seperti Gracilaria sp., alga coklat seperti Laminaria sp. dan alga hijau seperti Ulva sp. sebagai makanannya (Setyono, 2004). Tingkat kesukaan abalon terhadap rumput laut mungkin bervariasi antar spesies abalon. Setyono (2006) melaporkan bahwa H. asinina lebih menyukai Gracilaria sp. Jenis alga merah ini selain disukai juga mendukung pertumbuhan yang baik untuk abalon $H$. asinina (Capinpin \& Corre, 1996) dan H. squamata (Susanto et al., 2010). Namun dilaporkan juga bahwa abalon $H$. squamata sangat menyukai Ulva sp. segar. Rahmawati et al. (2008) melaporkan pertumbuhan abalon $H$. squamata terbaik diperoleh pada abalon yang diberi pakan Ulva sp. dibandingkan dengan yang diberi pakan Gracilaria sp. maupun Euchema sp. Sementara Cornwall et al. (2009) melaporkan bahwa abalon $H$. iris lebih menyukai pakan rumput laut dari jenis alga biru dibandingkan dengan alga merah atau alga hijau. Alcantara \& Noro (2006) melaporkan abalon $H$. diversicolor tumbuh lebih baik dengan pemberian pakan Sargassum fusiforma dan Ulva pertusa. Ketersediaan makro alga segar yang cukup dan kontinu menjadi perhatian tersendiri bagi keberlanjutan pengembangan budidaya abalon mengingat ketersediaan makro alga segar tersebut sangat tergantung pada musim. Untuk itu, upaya pengembangan pakan buatan sebagai pengganti makro alga segar perlu mendapat perhatian serius khususnya untuk budidaya abalon dalam bak. Hasil penelitian menunjukkan bahwa beberapa spesies abalon seperti $H$. squamata (Marzuqi et al., 2012), H. midae (Britz et al., 1997; Goosen et al., 2014), H. asinina (Bautista-Teruel \& Millamena, 1999), H. laevigata (Lange et al., 2014), dan H. fulgens (Gomes-Montes et al., 2003; Garcia-Esquivel et al., 2007) juga dapat memanfaatkan pakan buatan berupa pelet kering sebagai pakannya dan memberikan respons pertumbuhan yang baik.

Untuk menunjang keberlanjutan budidaya pembesaran abalon maka perlu dikembangkan pakan buatan yang sesuai dan efektif untuk abalon sebagai alternatif pengganti makro alga segar. Penelitian ini bertujuan untuk mendapatkan informasi dasar tentang bahan baku pakan potensial untuk pengembangan pakan buatan dan respons pertumbuhan abalon $H$. squamata terhadap pakan buatan.

\section{BAHAN DAN METODE}

\section{Inventarisasi dan Analisis Komposisi Bahan Baku Pakan}

Bahan baku pakan dari beberapa jenis rumput laut diperoleh dari beberapa lokasi, yaitu: Ulva sp. dari perairan Benoa (Kabupaten Badung, Bali), Gracilaria sp. tambak dari pembudidaya rumput laut di Situbondo (Jawa Timur), Gracilaria sp. laut dari perairan Pantai Gondol (Kabupaten Buleleng, Bali), dan Sargassum sp. dari perairan Pantai Pekutanan (Jembrana, Bali). Rumput laut dikeringkan dalam oven pada suhu $70^{\circ} \mathrm{C}$ dan selanjutnya dibuat menjadi tepung halus. Tepung disimpan dalam cold storage untuk analisis komposisi kimia dan sebagai bahan pembuatan pakan percobaan.

Analisis komposisi nutrien bahan baku pakan rumput laut yang meliputi komposisi proksimat, 
komposisi asam amino, dan asam lemak dilakukan di Laboratorium Terpadu Institut Pertanian Bogor. Komposisi proksimat dianalisis berdasarkan metode AOAC (1990) dan Takeuchi (1988). Kandungan protein ditentukan dengan metode Kjeldah, kadar lemak dengan metode soxlet, kadar abu dengan metode gravimetri setelah pembakaran bahan dalam tanur pada suhu $550^{\circ} \mathrm{C}$ dan karbohidrat dengan metode fenol sulfat dan spektrofotometer. Komposisi asam lemak dianalisis menggunakan Gas Chromatography (GC) dan komposisi asam amino ditentukan dengan High Performance Liquid Chromatography (HPLC).

\section{Aplikasi Pakan Buatan pada Pembesaran Abalon di Dalam Bak}

Empat pakan percobaan diformulasi menggunakan tepung rumput laut hasil koleksi sebagai bahan baku pakan. Pakan percobaan diformulasi dengan kombinasi tepung rumput laut yang berbeda seperti tertera pada Tabel 1. Adonan bahan pakan dicetak menjadi pelet menggunakan mesin pelet "Royal" dan dikeringkan menggunakan oven pada suhu $60^{\circ} \mathrm{C}$. Pakan kering disimpan dalam refrigerator sebelum dan selama dimanfaatkan untuk percobaan.
Wadah yang digunakan pada percobaan ini adalah 15 buah bak beton berukuran $2 \mathrm{~m}$ x 0,5 m x 0,5 m dengan ketinggian air $25 \mathrm{~cm}$. Bak dilengkapi dengan sistem air mengalir $15 \mathrm{~L} / \mathrm{min}$. dan aerasi sebagai pasok oksigen. Benih abalon yang digunakan berasal dari hatcheri dan mempunyai ukuran bobot rata-rata $3,07 \pm 1,11 \mathrm{~g}$; panjang cangkang 2,79 $\pm 0,27 \mathrm{~cm}$; serta lebar cangkang 1,67 $\pm 0,19 \mathrm{~cm}$, dengan kepadatan 400 ekor/bak (Heath \& Moss, 2009; Badillo et al., 2007). Selama penelitian, abalon diberi pakan berupa pelet kering sesuai perlakuan dan diberikan sebanyak dua kali sehari. Sebagai kontrol digunakan pakan berupa rumput laut Gracilaria sp. segar asal tambak dan diberikan sekali setiap hari. Pembersihan kotoran dan sisa pakan dilakukan dengan cara pencucian dasar bak setiap hari sebelum pemberian pakan.

Percobaan dirancang dengan rancangan acak lengkap (RAL) dengan lima perlakuan yaitu empat macam pakan percobaan berupa pelet kering dengan kombinasi tepung rumput laut yang berbeda dan satu pakan berupa rumput laut Gracilaria sp. segar asal tambak sebagai kontrol. Setiap perlakuan terdiri dari tiga ulangan. Untuk mengetahui respons abalon terhadap pakan percobaan, setiap dua bulan dilaku-

Tabel 1. Komposisi (g/100 g pakan) dan hasil analisis proksimat serta kecernaan pakan percobaan Table 1. Composition (g/100 $\mathrm{g}$ diet), proximate analysis and digestibility of test diets

\begin{tabular}{|c|c|c|c|c|}
\hline \multirow{2}{*}{ Bahan (Ingredients ) } & \multicolumn{4}{|c|}{ Pakan percobaan (Test diet) } \\
\hline & 1 & 2 & 3 & 4 \\
\hline Tepung Ulva sp. (Ulva sp. meal) & 18 & 18 & 18 & 0 \\
\hline Tepung Gracilaria sp. tambak (Gracilaria sp. meal from the sea) & 36.25 & 0 & 0 & 35 \\
\hline Tepung Gracilaria sp. laut (Gracilaria sp. meal from the pond) & 0 & 35.25 & 0 & 0 \\
\hline Tepung Sargassum sp. (Sargassum sp. meal) & 0 & 0 & 31.25 & 15.25 \\
\hline Tepung ikan (Fish meal) & 18 & 18 & 21 & 21 \\
\hline Tepung kedelai (Soybean meal) & 19 & 20 & 21 & 20 \\
\hline Vitamin mix & 2 & 2 & 2 & 2 \\
\hline Mineral mix & 3 & 3 & 3 & 3 \\
\hline Minyak ikan (Fish oil) & 3 & 3 & 3 & 3 \\
\hline Carboxy Methyl Cellulose (CMC) & 0.75 & 0.75 & 0.75 & 0.75 \\
\hline Total & 100 & 100 & 100 & 100 \\
\hline \multicolumn{5}{|l|}{ Komposisi proksimat pakan (Proximate composition of test diet) } \\
\hline Kadar air (Moisture) (\%) & 5.74 & 6.18 & 7.58 & 5.37 \\
\hline Protein $(\% \mathrm{DM})$ & 31.25 & 31.35 & 29.73 & 28.31 \\
\hline Lemak (Lipid) (\% DM) & 7.07 & 7.27 & 7.61 & 7.28 \\
\hline Kadar tepung abu (Ash) (\% DM) & 30.19 & 30.57 & 25.81 & 30.91 \\
\hline Serat kasar (Fiber) (\% DM) & 5.25 & 4.73 & 4.67 & 4.37 \\
\hline Karbohidrat (Carbohydrate) (\% DM) & 26.24 & 26.08 & 32.18 & 29.13 \\
\hline $\begin{array}{l}\text { Koefisien kecernaan pakan } \\
\text { Feed digestibility coeficient }\left(A D C_{d m}\right)(\%)\end{array}$ & 77.6 & 74.5 & 73.9 & 72.0 \\
\hline $\begin{array}{l}\text { Koefisien kecernaan protein pakan } \\
\text { Feed protein digestibility coeficient }\left(A D C_{c p}\right)(\%)\end{array}$ & 86.0 & 84.1 & 82.1 & 79.6 \\
\hline
\end{tabular}


kan pengukuran bobot, panjang, dan lebar cangkang abalon terhadap 40-80 ekor abalon dari masing-masing unit percobaan. Selama percobaan juga dilakukan pencatatan terhadap abalon yang mati sebagai dasar untuk menghitung sintasan abalon selama enam bulan percobaan.

\section{Penentuan Kecernaan Bahan Pakan dan Pakan Percobaan}

Wadah yang digunakan untuk menentukan kecernaan bahan pakan dan kecernaan pakan percobaan adalah bak polikarbonat volume 30 liter yang dilengkapi dengan sistem air mengalir dan aerasi. Abalon dengan ukuran bobot rata-rata 6,82 $\pm 1,22 \mathrm{~g}$ ditebar dengan kepadatan 30 ekor/bak. Pada pakan uji dan pakan referensi untuk penentuan kecernaan bahan pakan dan pakan percobaan ditambahkan kromium oksida $\left(\mathrm{Cr}_{2} \mathrm{O}_{3}\right)$ masing-masing sebanyak $1 \%$ sebagai indikator (Furuichi, 1988). Komposisi pakan referensi dan pakan uji untuk penentuan kecernaan bahan pakan disajikan pada Tabel 2 .

Abalon terlebih dahulu diadaptasikan dengan pakan percobaan selama satu minggu sebelum dilakukan pengumpulan feses. Abalon diberi pakan secara berlebih dua kali sehari pada pagi dan sore hari. Sisa pakan dan kotoran dalam bak dibersihkan tiga jam setelah pemberian pakan. Pengumpulan feses dilakukan secara berkala dengan cara penyiponan untuk mencegah terlarutnya nutrien pada feses. Feses yang terkumpul disimpan dalam freezer dan setelah mendapatkan jumlah yang cukup, feses dikeringkan dengan oven. Konsentrasi kromium dalam contoh pakan dan feses dianalisis berdasarkan prosedur Takeuchi (1988). Koefisien kecernaan bahan kering dan protein dari pakan percobaan dihitung dengan rumus Takeuchi (1988):

$$
\operatorname{ADC}(\%)=100 \times\left\{1-\left(M_{D} \times A_{F}\right) /\left(M_{F} \times A_{D}\right)\right\}
$$

di mana:

$\mathrm{ADC}=$ Apparent digestibility coeficient (koefisien kecernaan) dari bahan kering atau nutrien (protein kasar); $M_{D}$ dan $M_{F}$ berturut-turut adalah kadar kromium dalam pakan dan feses; $A_{D}$ dan $A_{F}$ berturut-turut adalah kadar nutrien dalam pakan dan dalam feses

Sementara itu, koefisien kecernaan (ADC) dari bahan pakan (tepung Ulva, tepung Gracilaria tambak, tepung Gracilaria laut, dan tepung Sargassum) dihitung berdasarkan Pfeffer et al. (1995) dan Forster (1999) dengan formula sebagai berikut:

$$
\mathrm{ADC}_{\mathrm{INGR}}(\%)=1 / \alpha\left\{\mathrm{AD}_{\mathrm{TD}}-(1-\alpha) \mathrm{AD}_{\mathrm{RD}}\right\}
$$

di mana:

$\mathrm{ADC}_{\text {INGR, }} \mathrm{AD}_{\mathrm{TD}}$ dan $\mathrm{AD}_{\mathrm{RD}}$ berturut-turut adalah koefisien kecernaan nutrien bahan pakan (tepung Ulva, tepung Gracilaria tambak, tepung Gracilaria laut, dan tepung Sargassum), pakan uji, dan pakan referensi; $\alpha$ adalah nilai substitusi yang dihitung berdasarkan proporsi nutrien yang dikontribusikan oleh bahan uji (tepung Ulva, tepung Gracilaria tambak, tepung Gracilaria laut, dan tepung Sargassum) dalam pakan referensi (Bureau et al., 1999)

\section{Analisis Data}

Untuk mengetahui respons abalon terhadap pakan percobaan, data bobot akhir, pertambahan bobot, panjang dan lebar cangkang, sintasan, serta kon-

Tabel 2. Komposisi pakan percobaan penentuan kecernaan bahan pakan (g/100 g)

\begin{tabular}{|c|c|c|}
\hline \multirow{2}{*}{$\begin{array}{c}\text { Bahan } \\
\text { Ingredients }\end{array}$} & \multirow{2}{*}{$\begin{array}{c}\text { Pakan referensi } \\
\text { Reference diet }\end{array}$} & \multirow{2}{*}{$\frac{\text { Pakan uji (Test diet) }}{\text { A, B, C, D }}$} \\
\hline & & \\
\hline Tepung Ulva sp. (Ulva sp. meal) & 46 & 32.2 \\
\hline Tepung ikan (Fish meal) & 25 & 17.5 \\
\hline Tepung kedelai (Soybean meal) & 19.25 & 13.48 \\
\hline Vitamin mix & 2 & 1.4 \\
\hline Mineral mix & 3 & 2.1 \\
\hline Minyak ikan (Fish oil) & 3 & 2.1 \\
\hline Carboxy Methyl Cellulose (CMC) & 0.75 & 0.75 \\
\hline Bahan uji (Test ingredients) & - & 29.47 \\
\hline $\mathrm{Cr}_{2} \mathrm{O}_{3}$ & 1 & 1 \\
\hline Total & 100 & 100 \\
\hline
\end{tabular}

Table 2. Composition of test diet for digestibility study of test ingredient (g/100 g)

Keterangan (Note):

$\mathrm{A}=$ Tepung Ulva sp. (Ulva sp. meal); B = Tepung Gracilaria sp. asal tambak (Gracilaria sp. meal from the pond); $\mathrm{C}=$ Tepung Gracilaria sp. asal laut (Gracilaria sp. meal from the sea), dan (and) D = Tepung Sargassum sp. (Sargassum sp. meal) 
versi pakan abalon dianalisis ragam (ANOVA) dan dilanjutkan dengan uji Tukey pada selang kepercayaan 95\% (Steel \& Torrie, 1980). Data komposisi proksimat bahan pakan disajikan secara tabulasi.

\section{HASIL DAN BAHASAN}

Empat jenis rumput laut yaitu: Ulva sp., Gracilaria sp. dari hasil budidaya di tambak, Gracilaria sp. dan Sargassum sp. yang tumbuh secara alami di laut merupakan bahan yang cukup berlimpah ketersediaannya. Rumput laut ini dalam bentuk segar juga telah dilaporkan sebagai makanan alami abalon di alam atau digunakan sebagai pakan pada budidaya abalon. Komposisi proksimat keempat rumput laut ini tertera pada Tabel 3. Kandungan bahan kering Ulva sp. adalah 4,68\% terendah dibandingkan dengan tiga jenis rumput laut lainnya. Sedangkan Sargassum sp. ternyata mempunyai kandungan bahan kering tertinggi $(23,62 \%)$. Walaupun kandungan bahan kering Ulva sp. paling rendah tetapi kandungan proteinnya adalah tertinggi (23,59\%). de Padua et al. (2004) melaporkan kandungan protein Ulva lactuca berkisar 15,23\%-18,35\% dan Ulva fasciata 13,30\%-16,13\% bervariasi dipengaruhi musim dan lingkungan tumbuhnya. Memperhatikan kandungan proteinnya, maka Ulva sp. merupakan salah satu bahan baku pakan potensial untuk abalon. Gracilaria sp. baik dari hasil budidaya di tambak maupun yang dari laut mempunyai kandungan protein 14,3\%-15,2\%; jauh lebih rendah dari kandungan protein Ulva sp. Demikian juga halnya dengan Sargassum sp. yang kandungan proteinnya paling rendah (7,94\%). Ungson (2003) melaporkan kandungan pro- tein Sargassum sp. memang bervariasi tergantung spesiesnya. Sargassum polycystum dan S. cristaefolium mempunyai kandungan protein masing-masing 6,25\% dan 3,45\%. Kedua jenis Sargassum ini juga dilaporkan memberikan respons pertumbuhan yang sama untuk abalon $H$. asinina, tetapi dengan jumlah konsumsi $S$. cristaefolium yang jauh lebih tinggi untuk memenuhi kebutuhan proteinnya. Keempat rumput laut yang dianalisis pada percobaan ini mempunyai kandungan karbohidrat yang cukup tinggi (24,69\%-50,57\%) dan menunjukkan pola yang terbalik dengan kandungan proteinnya. Mengingat abalon merupakan hewan herbivora maka karbohidrat ini dapat merupakan sumber energi yang sangat baik bagi abalon.

Komposisi asam amino keempat rumput laut yang dikoleksi disajikan pada Tabel 4 , yang mana terlihat bahwa Ulva sp. mempunyai komposisi asam amino esensial yang paling baik di mana konsentrasi masingmasing asam amino esensialnya lebih tinggi dibandingkan dengan tiga jenis rumput laut lainnya. Komposisi dan kandungan masing-masing asam amino esensial Gracilaria sp. tambak dan Gracilaria sp. laut hampir sama, kecuali kandungan metionin Gracilaria sp. laut yang lebih rendah. Sargassum sp. mempunyai komposisi dan kandungan asam amino esensial yang paling rendah. Kualitas protein dari bahan pakan dapat ditentukan dengan metode menghitung skor kimia. Hal ini berdasarkan bahwa nilai nutrisi protein sangat ditentukan oleh jumlah asam amino esensial yang defisien pada protein bahan tersebut dibandingkan dengan protein standar. Dengan menggunakan metode skor kimia, kualitas protein dari keempat

Tabel 3. Komposisi proksimat, kecernaan bahan kering, dan kecernaan protein rumput laut sebagai bahan baku pakan abalon

Table 3. Proximate composition, dry matter, and protein digestibility of seaweed as feed ingredient for abalone

\begin{tabular}{|c|c|c|c|c|}
\hline \multirow{3}{*}{$\begin{array}{l}\text { Parameter } \\
\text { Parameters }\end{array}$} & \multicolumn{4}{|c|}{ Bahan pakan uji (Test ingredients) } \\
\hline & \multirow{2}{*}{ Ulva sp. } & \multicolumn{2}{|c|}{ Gracilaria sp. } & \multirow{2}{*}{ Sargassum sp } \\
\hline & & Tambak (Pond) & Laut (Sea) & \\
\hline Kadar air (Moisture) (\%) & 95.32 & 88.70 & 91.34 & 76.38 \\
\hline Protein (\% DM) & 23.59 & 15.20 & 14.33 & 7.94 \\
\hline Lemak (Lipid) (\% DM) & 0.41 & 0.33 & 0.62 & 0.72 \\
\hline Kadar abu (Ash) (\% DM) & 47.89 & 46.88 & 48.10 & 35.84 \\
\hline Serat kasar (Fiber) (\% DM) & 3.42 & 4.88 & 5.84 & 4.93 \\
\hline Karbohidrat (Carbohydrate ) (\% DM) & 24.69 & 32.71 & 31.10 & 50.57 \\
\hline $\mathrm{ADC}_{\mathrm{INGR}}{ }^{*}$ & $86.1 \pm 0.2$ & $65.9 \pm 0.8$ & $65.8 \pm 1.2$ & $50.0 \pm 1.1$ \\
\hline $\mathrm{ADC}_{\mathrm{cp}}$ & $96.5 \pm 0.5$ & $94.9 \pm 0.3$ & $94.1 \pm 1.1$ & $91.5 \pm 0.5$ \\
\hline
\end{tabular}

Keterangan (Note):

Nilai rata-rata dari dua ulangan analisis (Average value from two analysis replications); $\mathrm{ADC}_{\mathrm{INGR}}=\mathrm{Koefisien}$ kecernaan bahan kering (Dry matter digestibility coeficient); dan (and) $\mathrm{ADC}_{\mathrm{cp}}=$ Koefisien kecernaan protein bahan pakan (Feed protein digestibility coeficient) 
Tabel 4. Komposisi asam amino rumput laut sebagai bahan pakan abalon $(\% \mathrm{w} / \mathrm{w})$ Table 4. Amino acid composition of seaweed as feed ingredient for abalone $(\% \mathrm{w} / \mathrm{w})$

\begin{tabular}{lcccc}
\hline \multirow{2}{*}{$\begin{array}{c}\text { Asam amino } \\
\text { Amino acids (AA) }\end{array}$} & Ulva sp. & \multicolumn{2}{c}{ Gracilaria sp. } & Sargassum sp. \\
& & & & \\
\hline AA esensial (Essential AA) & & & & \\
Leusin & 1.22 & 0.93 & 0.93 & 0.56 \\
Metionin & 0.26 & 0.24 & 0.15 & 0.17 \\
Isoleusin & 0.88 & 0.72 & 0.72 & 0.41 \\
Valin & 1.05 & 0.76 & 0.76 & 0.42 \\
Arginin & 1.04 & 0.71 & 0.65 & 0.33 \\
Treonin & 0.73 & 0.55 & 0.56 & 0.31 \\
Histidin & 0.31 & 0.18 & 0.20 & 0.12 \\
Fenilalanin & 0.88 & 0.60 & 0.62 & 0.38 \\
Lisin & 0.83 & 0.64 & 0.63 & 0.37 \\
\hline AA non esensial (Non essential $A A)$ & & & & \\
Alanin & 1.35 & 0.79 & 0.78 & 0.53 \\
Asam Aspartat & 2.02 & 1.33 & 1.28 & 0.91 \\
Asam Glutamat & 2.17 & 1.55 & 1.65 & 1.30 \\
Glisin & 0.88 & 0.64 & 0.63 & 0.35 \\
Serin & 0.64 & 0.44 & 0.49 & 0.24 \\
Tirosin & 0.44 & 0.44 & 0.34 & 0.17 \\
\hline
\end{tabular}

rumput laut yang dikoleksi ditentukan oleh kandungan asam amino metionin dan lisin. Kandungan kedua asam amino tersebut jauh lebih rendah dibandingkan dengan yang standar.

Komposisi asam lemak keempat jenis rumput laut yang dikoleksi sebagai bahan baku pakan abalon disajikan pada Tabel 5. Gracilaria sp. tambak dan laut mempunyai kandungan asam lemak linolenat (18:3n3) lebih rendah dibandingkan dengan Ulva sp. atau Sargassum sp. Sementara kandungan EPA (20:5n-3) kedua rumput laut tersebut justru tinggi. Gracilaria sp. tambak juga mempunyai kandungan linoleat (18: 2n6) dan DHA (22:6n3) yang rendah. Walaupun kandungan masing-masing asam lemak n-3 dari rumput laut tersebut bervariasi, tetapi kandungan total asam lemak n-3-nya hampir sama. Kandungan total asam lemak n-6 Sargassum sp. adalah tertinggi yang terdiri atas asam lemak linolenat (18:2n-6) dan asam lemak arachidonat (20:4n-6). Hal yang sebaliknya ditunjukkan oleh kandungan asam lemak Ulva sp. Asam lemak n-3 dan n-6 tersebut merupakan asam lemak esensial bagi sebagian besar hewan laut.

Keragaan pertumbuhan abalon $H$. squamata yang diberi pakan percobaan dengan beda campuran tepung rumput laut disajikan pada Tabel 6. Pertumbuhan abalon yang dinyatakan dengan bobot akhir, persentase pertambahan bobot, panjang cangkang dan lebar cangkang dipengaruhi oleh proporsi tepung rumput laut dalam pakan. Abalon yang diberi pakan mengandung campuran tepung Ulva sp. dengan Gracilaria sp. tambak atau campuran tepung Gracilaria sp. tambak dengan Sargassum sp. memberikan pertumbuhan lebih baik dan berbeda nyata $(\mathrm{P}<0,05)$ dibandingkan dengan yang diberi campuran tepung rumput laut lainnya. Pertumbuhan paling rendah diperoleh pada abalon yang diberi pakan mengandung campuran tepung Ulva sp. dengan Gracilaria sp. laut (Tabel 6). Namun demikian pertumbuhan abalon yang diberi pakan Gracilaria sp. tambak segar menghasilkan pertumbuhan paling tinggi dan berbeda nyata $(\mathrm{P}<0,05)$ dengan semua perlakuan lainnya. Hal ini menunjukkan masih ada permasalahan dalam pemanfaatan pakan buatan berupa pelet kering oleh abalon. Abalon yang dimanfaatkan untuk percobaan memang belum pernah diberikan pakan buatan, baik selama pemeliharaan larva maupun selama pendederan. Sehingga sebelum dimanfaatkan untuk percobaan diperlukan waktu yang relatif lama (satu bulan) untuk adaptasi terhadap pakan buatan. Dari hasil penelitian ini diperoleh bahwa Gracilaria sp. tambak baik dalam bentuk segar maupun kering (tepung) mempunyai peran lebih signifikan dalam menunjang pertumbuhan abalon $H$. squamata. Tepung Ulva sp. selain sebagai bahan pakan, juga dilaporkan mengandung senyawa bioaktif dan antioksidan yang berperan menekan mortalitas akibat meningkatnya suhu air pada musim panas (Lange et al., 2014). 
Tabel 5. Komposisi asam lemak rumput laut sebagai bahan pakan abalon (\% $w / w$ in fat)

Table 5. Fatty acid composition of seaweed as feed ingredient for abalone (\% $\mathrm{w} / \mathrm{w}$ in fat)

\begin{tabular}{lcccc}
\hline \multirow{2}{*}{$\begin{array}{c}\text { Asam lemak } \\
\text { Fatty acids }\end{array}$} & Ulva sp. & \multicolumn{2}{c}{ Gracilaria sp. } & Sargassum sp. \\
\cline { 3 - 4 } & & Tambak (Pond) & Laut (Sea) & \\
\hline $14: 00$ & 1.00 & 0.26 & 2.93 & 1.4 \\
$16: 00$ & 8.65 & 9.49 & 15.64 & 10.21 \\
$18: 00$ & 1.53 & 0.61 & 1.72 & 0.59 \\
$18: 1 \mathrm{n}-9$ & 4.43 & 3.11 & 6.67 & 3.46 \\
$18: 2 \mathrm{n}-6$ & 1.15 & 0.52 & 1.37 & 3.15 \\
$18: 3 \mathrm{n}-3$ & 1.98 & 0.05 & 0.04 & 2.06 \\
$20: 4 \mathrm{n}-6$ & 0.34 & 5.14 & 2.15 & 8.32 \\
$20: 5 \mathrm{n}-3$ & 0.97 & 3.74 & 2.11 & 1.59 \\
$22: 6 \mathrm{n}-3$ & 0.81 & 0.09 & 1.75 & 0.09 \\
\hline Total $\mathrm{n}-3$ & 3.76 & 3.88 & 3.90 & 3.74 \\
Total n-6 & 1.49 & 5.66 & 3.52 & 11.47 \\
\hline
\end{tabular}

Tabel 6. Bobot akhir, persentase pertambahan bobot, panjang cangkang, lebar cangkang, sintasan, dan konversi pakan abalon Haliotis squamata yang diberi pakan percobaan

Table 6. Final weight, percentage weight gain, shell length, shell width, survival, and feed conversion ratio (FCR) of abalone Haliotis squamata fed experimental diet

\begin{tabular}{ccccccc}
\hline $\begin{array}{c}\text { Pakan } \\
\text { percobaan } \\
\text { Test diet }\end{array}$ & $\begin{array}{c}\text { Bobot akhir } \\
\text { Final weight } \\
\mathbf{( g )}\end{array}$ & $\begin{array}{c}\text { Pertambahan bobot } \\
\text { Weight gain } \\
\mathbf{( \% )}\end{array}$ & $\begin{array}{c}\text { Panjang cangkang } \\
\text { Shell length } \\
(\mathbf{c m})\end{array}$ & $\begin{array}{c}\text { Lebar cangkang } \\
\text { Shell width } \\
(\mathbf{c m})\end{array}$ & $\begin{array}{c}\text { Sintasan } \\
\text { Survival rate } \\
(\mathbf{\%})\end{array}$ & $\begin{array}{c}\text { Konversi } \\
\text { pakan } \\
\text { FCR }\end{array}$ \\
\hline 1 & $7.79 \pm 0.17^{\mathrm{a}}$ & $181.4 \pm 49.5^{\mathrm{a}}$ & $3.76 \pm 0.03^{\mathrm{a}}$ & $2.25 \pm 0.02^{\mathrm{a}}$ & $92.2 \pm 8.3^{\mathrm{a}}$ & $1.87 \pm 0.28^{\mathrm{a}}$ \\
2 & $5.90 \pm 0.37^{\mathrm{b}}$ & $116.0 \pm 31.3^{\mathrm{b}}$ & $3.39 \pm 0.10^{\mathrm{b}}$ & $2.06 \pm 0.03^{\mathrm{b}}$ & $91.3 \pm 3.9^{\mathrm{a}}$ & $2.38 \pm 0.22^{\mathrm{a}}$ \\
3 & $6.73 \pm 0.28^{\mathrm{ab}}$ & $123.0 \pm 21.1^{\mathrm{ab}}$ & $3.51 \pm 0.07^{\mathrm{ab}}$ & $2.12 \pm 0.03^{\mathrm{ab}}$ & $90.5 \pm 3.2^{\mathrm{a}}$ & $2.48 \pm 0.17^{\mathrm{a}}$ \\
4 & $7.32 \pm 0.34^{\mathrm{a}}$ & $156.7 \pm 38.2^{\mathrm{ab}}$ & $3.61 \pm 0.15^{\mathrm{ab}}$ & $2.20 \pm 0.06^{\mathrm{ab}}$ & $87.7 \pm 8.8^{\mathrm{a}}$ & $2.11 \pm 0.14^{\mathrm{a}}$ \\
5 & $12.64 \pm 1.12^{\mathrm{c}}$ & $263.4 \pm 14.4^{\mathrm{c}}$ & $4.21 \pm 0.18^{\mathrm{c}}$ & $2.59 \pm 0.10^{\mathrm{c}}$ & $82.6 \pm 15.4^{\mathrm{a}}$ & $2.24 \pm 0.32^{\mathrm{a}}$ \\
\hline
\end{tabular}

Nilai dalam kolom yang sama diikuti oleh superscript huruf yang sama menunjukkan tidak berbeda nyata $(\mathrm{P}>0,05)($ Values in the same column followed by the same superscript letter are not significantly different $(P>0.05))$

Tingkat preferensi abalon terhadap berbagai jenis rumput laut segar mungkin berbeda menurut spesiesnya. Setyono (2006) melaporkan bahwa abalon $H$. asinina lebih menyukai Gracilaria sp. Tetapi pertumbuhan abalon yang hanya diberi pakan Gracilaria sp. hampir sama dengan yang diberi pakan Ulva sp. Pertumbuhan abalon H. asinina terbaik justru diperoleh pada abalon yang diberi pakan campuran beberapa rumput laut termasuk Gracilaria sp. dan Ulva sp. Abalon H. diversicolor yang dipelihara pada keranjang apung di laut tumbuh lebih baik dengan pakan Sargassum fusiforma dan Ulva pertusa (Alcantara \& Noro, 2006). Namun dari aspek tingkat kesukaannya, abalon $H$. diversicolor lebih menyukai Sargassum fusiforma daripada Ulva pertusa (Alcantara \& Noro, 2005). Dalam upaya mendapatkan substitusi kelp (Laminari japonica) sebagai pakan abalon $H$. discus hannai, Qi et al. (2010) mengevaluasi penggunaan Sargassum pallidum dan Gracilaria lemaneiformis sebagai pakan. Hasil percobaan tersebut menunjukkan bahwa G. lemaneiformis memberikan respons makan dan pertumbuhan abalon yang lebih baik dibandingkan $S$. pallidum. Rusdi et al. (2010) menyatakan stok induk abalon $H$. squamata tumbuh paling baik dengan pemberian pakan kombinasi antara Gracilaria sp., Ulva sp., dan Sargassum sp. dibandingkan dengan pemberian pakan hanya salah satu dari rumput laut tersebut. Pada pembesaran abalon $H$. squamata dengan wadah waskom plastik yang digantung pada rakit di laut dan diberi pakan rumput laut segar dengan proporsi berbeda diperoleh bahwa proporsi Gracilaria sp. tambak/Ulva sp. $60 \% / 40 \%$ menghasilkan pertumbuhan abalon yang terbaik (Giri et al., 2014). Pada percobaan tersebut peningkatan proporsi Ulva sp. dari $0 \%$ sampai $40 \%$ menghasilkan pertumbuhan abalon yang meningkat. Pada pendederan benih abalon 
H. squamata menggunakan pakan buatan pelet kering dengan proporsi tepung Ulva sp. dan tepung Gracilaria sp. yang berbeda menunjukkan bahwa pertumbuhan abalon yang diberi pakan dengan proporsi tepung Ulva sp./tepung Gracilaria sp. 100\%/0\% sampai $50 \% / 50 \%$ dalam pakan tidak menghasilkan pertumbuhan abalon yang berbeda. Namun demikian, pertumbuhan abalon lebih rendah diperoleh pada proporsi tepung Ulva sp./tepung Gracilaria sp. 25\%/75\% (Marzuqi et al., 2012). Beberapa hasil penelitian tersebut menunjukkan bahwa penggunaan pakan kombinasi dari beberapa rumput laut adalah lebih baik dibandingkan hanya satu jenis rumput laut.

Ketersediaan rumput laut segar, terutama yang masih diperoleh dari alam akan sangat dipengaruhi oleh musim sehingga akan dapat menghambat keberlanjutan usaha budidaya abalon. Untuk itu, usaha penyediaan pakan buatan yang efektif untuk abalon menjadi sangat penting. Informasi kebutuhan nutrien pakan untuk abalon $H$. squamata belum tersedia. Namun demikian, informasi kebutuhan nutrien untuk jenis abalon lainnya dapat sebagai acuan pada pengembangan pakan buatan untuk $H$. squamata. Bautista-Teruel \& Millamena (1999) melaporkan level protein optimum untuk abalon $H$. asinina adalah $27 \%$ dengan kandungan energi $3.150 \mathrm{ME} / \mathrm{kg}$ pakan. Juga dilaporkan bahwa abalon yang diberi pakan buatan tersebut tumbuh lebih baik dibandingkan dengan yang diberi pakan segar Gracilariopsis brilinae. Rahman et al. (2012) mendapatkan pertumbuhan abalon hibrid (H. discus hannai $\mathrm{x} H$. sieboldii) yang baik dengan menggunakan pakan pelet mengandung $34 \%$ protein dan $4 \%$ lemak pada pemeliharaan dengan sistem resirkulasi. Abalon $H$. midae tumbuh baik dengan pakan buatan yang mengandung $5 \%$ lemak dan $30 \%$ protein dari tepung ikan, casein, dan Spirulina (Britz et al., 1997). Bahkan pakan tersebut memberikan respons pertumbuhan abalon lebih baik daripada abalon yang diberi pakan alga merah segar Plocamium corallorhiza. Hal berbeda dilaporkan Mai et al. (1995), di mana abalon $H$. tuberculata dan $H$. discus hanai tumbuh lebih baik dengan pakan alga merah segar
Palmaria palmata dibandingkan dengan yang diberi pakan pelet yang mengandung $25 \%$ protein dan $3,11 \%$ 7,09\% lemak.

Pada percobaan aplikasi pakan buatan ini, tingkat konsumsi pakan abalon yang diberi pakan rumput laut Gracilaria sp. segar ternyata jauh lebih tinggi (91 mg bobot kering/individu/hari) dibandingkan dengan yang diberi pakan pelet kering (49-50 mg bobot kering/individu/hari). Namun demikian, ternyata jumlah konsumsi proteinnya hampir sama, yaitu mencapai 14-15 mg protein/individu/hari. Data ini menunjukkan bahwa abalon akan mengonsumsi jumlah pakan yang berbeda untuk memenuhi kebutuhan proteinnya. Hal yang sama dilaporkan Ungson (2003) untuk abalon $H$. asinina yang diberi pakan dua jenis rumput laut, yaitu Sargassum cristaefolium dan S. polycystum yang mempunyai kandungan protein berbeda berturutturut $3,45 \%$ dan $6,26 \%$ menunjukkan bahwa jumlah konsumsi rumput laut dengan protein rendah jauh lebih tinggi dibandingkan dengan konsumsi rumput laut dengan kandungan protein yang lebih tinggi. Demikian juga untuk abalon Haliotis laevigata dilaporkan mengonsumsi pakan pelet yang mempunyai kandungan protein rendah lebih banyak dibandingkan dengan pakan pelet yang kandungan proteinnya tinggi.

Sintasan abalon diberi pakan percobaan berkisar antara $82,6 \%-92,2 \%$. Analisis ANOVA menunjukkan bahwa sintasan abalon tidak dipengaruhi oleh beda campuran tepung rumput laut dalam pakan $(\mathrm{P}>0,05)$. Kematian abalon terjadi setelah dilakukan pengukuran untuk mendapatkan data bobot dan panjang cangkang abalon. Hal ini mungkin dikarenakan adanya luka saat melepaskan abalon dari tempatnya menempel. Pada percobaan pendederan abalon $H$. laevigata menggunakan pakan buatan dan Ulva sp., Daume et al. (2007) melaporkan bahwa sintasan ablon yang diberi pakan buatan lebih tinggi (77\%-82\%) dibandingkan dengan yang diberikan pakan alga segar $(62 \%-65 \%)$.

Komposisi proksimat daging abalon setelah diberi pakan percobaan selama enam bulan disajikan pada Tabel 7. Kandungan bahan kering dan lemak

Tabel 7. Komposisi proksimat daging abalon yang diberikan pakan percobaan

Table 7. Proximate composition of abalone meat fed experimental diets

\begin{tabular}{ccccc}
\hline $\begin{array}{c}\text { Pakan percobaan } \\
\text { Test diet }\end{array}$ & $\begin{array}{c}\text { Bahan kering } \\
\text { Dry matter }(\%)\end{array}$ & $\begin{array}{c}\text { Protein kasar } \\
\text { Crude protein }(\% \mathrm{DM})\end{array}$ & $\begin{array}{c}\text { Lemak } \\
\text { Lipid }(\% \mathrm{DM})\end{array}$ & $\begin{array}{c}\text { Abu } \\
\text { Ash (\% DM) }\end{array}$ \\
\hline 1 & $21.6 \pm 0.1^{\mathrm{a}}$ & $69.8 \pm 1.4^{\mathrm{a}}$ & $7.0 \pm 0.8^{\mathrm{a}}$ & $11.7 \pm 0.5^{\mathrm{a}}$ \\
2 & $21.5 \pm 0.5^{\mathrm{a}}$ & $69.6 \pm 0.6^{\mathrm{a}}$ & $8.1 \pm 0.3^{\mathrm{a}}$ & $11.9 \pm 0.4^{\mathrm{a}}$ \\
3 & $20.9 \pm 0.4^{\mathrm{a}}$ & $69.6 \pm 1.2^{\mathrm{a}}$ & $7.6 \pm 0.8^{\mathrm{a}}$ & $12.1 \pm 0.4^{\mathrm{a}}$ \\
4 & $20.7 \pm 0.7^{\mathrm{a}}$ & $68.9 \pm 0.7^{\mathrm{a}}$ & $8.4 \pm 0.5^{\mathrm{a}}$ & $12.1 \pm 0.6^{\mathrm{a}}$ \\
5 & $20.9 \pm 0.8^{\mathrm{a}}$ & $55.8 \pm 0.8^{\mathrm{b}}$ & $6.4 \pm 1.1^{\mathrm{a}}$ & $9.5 \pm 0.5^{\mathrm{b}}$ \\
\hline
\end{tabular}


daging abalon tidak dipengaruhi oleh pakan percobaan $(P>0,05)$. Sementara itu, kandungan protein kasar daging abalon yang diberi pakan pelet kering jauh lebih tinggi dan berbeda nyata $(\mathrm{P}<0,05)$ dari abalon yang diberi pakan Gracilaria sp. segar dari tambak. Pada formulasi pakan pelet kering selain menggunakan campuran tepung rumput laut juga ditambahkan tepung ikan dan tepung kedelai untuk mendapatkan kandungan protein pakan yang sesuai. Penambahan tepung ikan dan tepung kedelai pada pakan pelet kering diduga berperan pada peningkatan kandungan protein daging abalon.

\section{KESIMPULAN}

Dari penelitian ini diperoleh informasi dasar tentang empat jenis rumput laut yang potensial dapat dimanfaatkan sebagai bahan baku pakan abalon $H$. squamata. Pakan dari campuran tepung rumput laut Gracilaria sp. tambak dengan Ulva sp. atau campuran Gracilaria sp. tambak dengan Sargassum sp. memberikan respons pertumbuhan yang baik dan merupakan bahan baku pakan yang baik untuk abalon $H$. squamata.

\section{DAFTAR ACUAN}

Alcantara, L., \& Noro, T. (2005). Effects of macroalgal type and water temperature on macroalgal consumption rates of the abalone Haliotis diversicolor Reeve. J. Shellfish Research, 24(4), 1169-1177.

Alcantara, L., \& Noro, T. (2006). Growth of the abalone Haliotis diversicolor (Reeve) fed with macroalgae in floating net cage and plastic tank. Aquaculture Research, 37(7), 708-717.

Association of Official Analytical Chemist (AOAC). (1990). Official methods of analysis. $12^{\text {th }}$ edition. Association of Official Analytical Chemists. Washington, D.C., 1141 pp.

Badillo, L., Segovia, M., \& Bernal, R.S. (2007). Effect of two stocking densities on the growth and mortality of the pink abalon Haliotis corrugata in recirculating and flow-trough systems. J. Shellfish Research, 26(3), 801-807.

Bansemer, M.S., Harris, J.O., Qin, J.G., Adams, L.R., Duong, D.N., \& Stone, D.A.J. (2015). Growth and feed utilisation of juvenile greenlip abalone (Haliotis laevigata) in response to water temperatures and increasing dietary protein levels. Aquaculture, 436, 13-20.

Bautista-Teruel, M.N., \& Millamena, O.M. (1999). Diet development and evaluation for juvenile abalone, Haliotis asinina: protein/energy levels. Aquaculture, 178, 117-126.

Britz, P.J., Hecht, T., \& Mangold, S. (1997). Effect of temperature on growth, feed consumption and nutritional indices of Haliotis midae fed a formulated diet. Aquaculture, 152, 191-203.

Bureau, D.P., Harris, A.M., \& Cho, C.Y. (1999). Apparent digestibility of rendered animal protein ingredients for rainbow trout (Oncorhynchus mykiss). Aquaculture, 180, 345-358.

Capinpin, Jr.E.C., \& Corre, K.G. (1996). Growth rate of the Philippine abalone, Haliotis asinina fed an artificial diet and macroalgae. Aquaculture, 144(13), 81-89.

Cornwall, C.E., Phillips, N.E., \& McNaught, D.C. (2009). Feeding preferences of the abalone $\mathrm{Ha}$ liotis iris in relation to macroalgal species, attachment, accessibility and water movement. J. Shellfish Research, 28(3), 589-597.

Daume, S., Davidson, M., Ryan, S., \& Parker, F. (2007). Comparisons on rearing systems based on algae or formulated feed for juvenile greenlip abalon (Haliotis leavigata). J. Shellfish Research, 26(3), 729735.

de Padua, M., Fontoura, P.S.G., \& Mathias, A.L. (2004). Chemical composition of Ulvaria oxysperma (Kutzing) Bliding, Ulva lactuca (Linnaeus) and Ulva fascita (Delile). Int. J. Brazilian Archives of Bioloby and Technology, 47(1), 49-55.

Forster, I. (1999). A note on the method of calculating digestibility coefficients of nutrients provided by single ingredients to feeds of aquatic animals. Aquaculture Nutrition, 5, 143-145.

Furuichi, M. (1988). Carbohydrate, In Watanabe, T. (Ed.). Fish Nutrition and Mariculture. Tokyo: Department of Aquatic Biosciences, University of Fisheries. p. 44-55.

Garcia-Esquivel, Z., Montes-Magallon, S., \& GonzalezGomes, M.A. (2007). Effect of temperature and photoperiod on the growth, feed consumption, and biological content of juvenile green abalone, Haliotis fulgens, fed on a balanced diet. Aquaculture, 262(1), 129-141.

Giri, I N.A., Sutarmat, T., Yudha, H.M., Rusdi, I., \& Susanto, B. (2014). Grow-out of abalone Haliotis squamata in floating cages fed different proportions of seaweed and with reduction of stocking density. Indonesian Aquaculture Journal, 9(1), 1521.

Gomez-Montes, L., Garcia-Esquivel, Z., D’Abramo, L.R., Shimada, A., Vasquez-Pelaez, C., \& Viana, M.T. (2003). Effect of dietary protein:energy ratio on intake, growth and metabolism of juvenile green abalone, Haliotis fulgens. Aquaculture, 222, 769780.

Gordon, H.R., \& Cook, P.A. (2001). World abalone fisheries and aquaculture update: supply and market dynamics. J. Shellfish Res., 20, 567-570. 
Goosen, N.J., de Wet, L.F., \& Görgens, J.F. (2014) Rainbow trout silage oil as immunity enhancing feed ingredient in formulated diets for South African abalone Haliotis midae. Aquaculture, 430, 2833.

Hahn, K.O. (1989). Artificial induction of spawning and fertilization. In Hahn, K.O. (Eds.). Handbook of culture of abalone and other marine gastropods CRC Press. Inc. Boca Raton. Florida, p. 5370.

Heath, P., \& Moss, G. (2009). Is the size grading important for farming the abalon Haliotis iris. Aquaculture, 290, 80-86.

Ikenoue, H., \& Kafuku, T. (1992). Modern methods of aquaculture in Japan. Elsevier, Kadansha Ltd. Tokyo, p. 206-216.

Lange, B., Currie, K., Howarth, G.S., \& Stone, D.A.J. (2014). Grape seed extract and dried macroalgae, Ulva lactuca Linnaeus, improve survival of greenlip abalone, Haliotis laevigata Donovan, at high water temperature. Aquaculture, 433, 348-360.

Mai, K., Mercer, J.P., \& Donlon, J. (1995). Comparative studies on the nutrition of two species of abalone, Haliotis tuberculata L. and Haliotisdiscus hannai Ino. III. Response of abalone to various levels of dietary lipid. Aquaculture, 134, 65-80.

Marzuqi, M., Rusdi, I., \& Susanto, B. (2012). Aplikasi pakan buatan pada pemeliharaan benih abalon (Haliotis squamata).J. Ris. Akuakultur, 7(2), 237-245.

Pfeffer, E., Kinzinger, S., \& Rodehutscord, M. (1995). Influence of the proportion of poultry slaughter by-products and of untreated or hydrothermically treated legume seeds in diets for rainbow trout, Oncorhynchus mykiss (Walbaum), on apperent digestibilities of their energy and organic compounds. Aquaculture Nutrition, 1, 111-117.

Qi, Z., Liu, H., Li, B., Mao, Y., Jiang, Z., Zhang, J., \& Fang, J. (2010). Suitability of two seaweeds, Gracilaria lemaneiformis and Sargassum pallidum, as feed for the abalone Haliotis discus hannai Ino. Aquaculture, 300, 189-193.

Rahman, M.M., Kadowaki, S., Linn, S.M., \& Yamada, Y. (2012). Land-based poly-eco-aquaculture of abalone and seaweed in a small scale recirculating system using a recycled freezer container. Bull. Fish. Res. Agen., 35, 77-84.

Rahmawati, R., Rusdi, I., \& Susanto, B. (2008). Studi tentang pertumbuhan abalon Haliotis squamata (Reeve, 1846) dengan pemberian pakan makroalga yang berbeda. Prosiding Seminar Nasional Perikanan Indonesia. Sekolah Tinggi Perikanan. Jakarta, hlm. 342-349.
Rusdi, I., Rahmawati, R., Susanto, B., \& Giri, I N.A. (2010). Pematangan gonad induk abalon Haliotis squamata melalui pengelolaan pakan. J. Ris. Akuakultur, 5(3), 383-391.

Rusdi, I., Susanto, B., \& Khotimah, F.H. (2012). Perbaikan teknik pendederan (H. squamata) skala massal. Laporan teknis Balai Besar Penelitian dan Pengembangan Budidaya Laut. Gondol, $12 \mathrm{hlm}$.

Setyono, D.E.D. (2004). Abalon (Haliotis asinina L.): 1. a prospective species for aquaculture in Indonesia. Oseana, XXIX(2), 25-30.

Setyono, D.E.D. (2006). Food preferences for juvenile tropical abalone (Haliotis asinina). Oseanologi dan Limnologi di Indonesia, 41, 1-14.

Steel, R.G.D., \& Torrie, J.H. (1980). Principles and procedures of statistics. McGraw Hill, New York. USA, 481 pp.

Susanto, B., Rusdi, I., \& Buda, M. (2008). Uji coba transportasi abalon (Haliotis squamata) kondisi hidup dengan metode kering. Prosiding Seminar Nasional Biodiversitas II. Departemen Biologi, Universitas Airlangga. Surabaya, hlm. 235-238.

Susanto, B., Rusdi, I., Ismi, S., \& Rahmawati, R. (2009). Pembenihan dan pembesaran abalon (Haliotis squamata) di Balai Besar Riset Perikanan Budidaya Laut, Gondol, Bali. Prosiding Seminar Nasional Moluska 2: "Moluska Peluang Bisnis dan Konservasi". FPIK-IPB. Bogor, hlm. 149-161.

Susanto, B., Rusdi, I., Ismi, S., \& Rahmawati, R. (2010). Pemeliharaan yuwana abalon (Haliotis squamata) turunan F-1 secara terkontrol dengan jenis pakan berbeda. J. Ris. Akuakultur, 5(2), 199-209.

Sutarmat, T., Yudha, H.T., \& Giri, I N.A. (2009). Optimalisasi substrat pada pembesaran abalon (Haliotis squamata) di KJA. Laporan Teknis. Balai Besar Riset Perikanan Budidaya Laut Gondol. Bali, hlm. 261-268.

Takashi. (1980). Abalone and their industry in Japan. Ministry of Agriculture, Forestry and Fisheries. Japan, p. 165-177.

Takeuchi, T. (1988). Laboratory work-chemical evaluation of dietary nutrient. In Watanabe, T. (Ed.). Fish nutrition and mariculture. JICA Kanagawa International Fisheries Training Centre. Tokyo, p. 179-233.

Ungson, J.R. (2003). Feeding of abalone juveniles with two species of Sargassum (Sargassum cristaefolium and Sargassum polycystum). Philippine Journal of Science, 132(1), 33-38. 